\title{
Field Notes
}

\section{THE BELOSSELSKY-BELOZERSKY COLLECTION OF RUSSIAN ART EXHIBITION AT THE UNIVERSITY OF GEORGIA}

This unique collection, spanning the period from 1660 to 1952 , is normally housed at the former "castle"/summer home of Richard Teller Crane II, younger brother of Charles R. Crane, near Ipswich, Massachusetts, where display space is limited. The collection is now on a rare tour to the Georgia Museum of Art on the campus of the University of Georgia in Athens. It was collected largely in the late century by philosopher and poet Prince Alexander Belosselsky- Belozersky and removed from Russia to Finland after the Bolshevik Revolution by Prince Konstantin Belosselsky-Belozersky, and then to the U.S. in 1951. It includes a large number of art works, especially portraits, much of which was considered lost after the revolution.

The exhibition featured a two day conference (September 21 and 22) highlighting the uniqueness of works of art. It will be on display at the University of Georgia until January 6, 2019. For more information regarding hours, etc. contact the museum at (706-542-4662 or mlachow@uga.edu).

Information provided by Edward Kasinec, Curator Emeritus, Slavic and Baltic Division, New York Public Library, Visiting Fellow, Hoover Institution. 


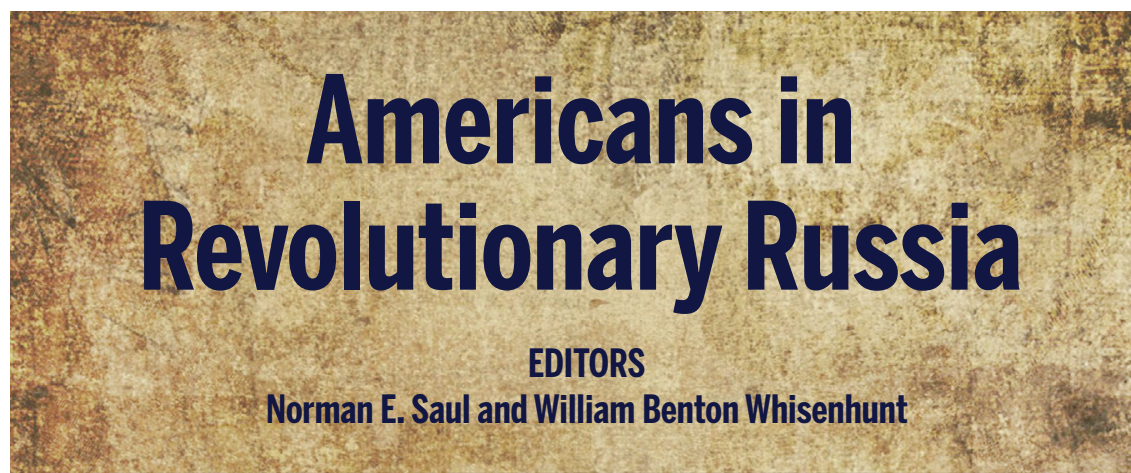

Published volumes

Julia Cantacuzène-Spéransky, Russian People: Revolutionary

Recollections (1920), edited by

Norman E. Saul

Ernest Poole, The Village: Russian Impressions (1919), edited by Norman E. Saul

Louise Bryant, Six Red Months in Russia (1918), edited by Lee A. Farrow

Edward Alsworth Ross, Russia in Upheaval (1918), edited by Rex A. Wade

Albert Rhys Williams, Through the Russian Revolution

(1921), edited by William

Benton Whisenhunt

John Reed, Ten Days That

Shook the World (1919), edited

by William Benton Whisenhunt

Donald Thompson, Donald

Thompson in Russia (1918),

edited by David Mould
Americans in Revolutionary

Russia is an exciting new series of

republications of books by American

eyewitnesses in Russia during the

turbulent Russian Revolutionary

Era (1914-21). The men and

women who wrote these accounts

left a rich treasure of insights on

a kaleidoscopic range of issues

such as politics, ethnic identity,

military, war, travel, and much

more, offering readers a first-hand view of a tumultuous, complex, and controversial era. Providing a broad range of American perspectives, the series accompanies each account with an expert introduction and annotation by a leading scholar in order to make the work accessible to the modern reader.
Forthcoming works

Arthur Bullard, The Russian Pendulum: Autocracy-

Democracy-Bolshevism (1919), edited by David McFadden

David R. Francis, Russia from the American Embassy, April 1916-November 1918 (1921), edited by Vladimir Noskov

Madeleine Z. Doty, Behind the Battlelines: Around the World in 1918 (1919), edited by Julia Mickenberg

Pauline S. Crosley, Intimate Letters from Petrograd (1920), edited by Lee A. Farrow

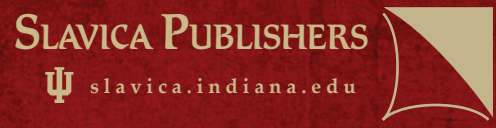




\section{Key Sessions at the ASEEES Convention in Boston, December 2018}

See - ASEEES.Org for more details

Getting Our Students to Perform: Creative Approaches to Teaching Russian History

Fri, December 7, 4:30 to 6:15pm, Boston Marriott Copley Place, 5th, New Hampshire

\section{US-Russia Public Diplomacy}

Sun, December 9, 10:00 to 11:45am, Boston Marriott Copley Place, 1st, Tremont

Russian-American War of Images in Popular Geopolitics: from Obama to Trump

Thu, December 6, 12:00 to 1:45pm, Boston Marriott Copley Place, 4th, Grand Ballroom Salon E

Great Patriotic Wars: Discourses of Nationalism and Patriotism in Post-Crimea Russia

Sat, December 8, 10:00 to 11:45am, Boston Marriott Copley Place, 1st, Columbus II

Communism on the Global Market: International Finance and Soviet Foreign Relations

Sun, December 9, 10:00 to 11:45am, Boston Marriott Copley Place, 4th, Hyannis

Soviet Speak: The Ritualization of Soviet Propaganda during the Cold War

Thu, December 6, 4:00 to 5:45pm, Boston Marriott Copley Place, 3rd, Exeter

Navigating the Enigma: Foreigners in Imperial and Soviet Russia Sun, December 9, 12:00 to 1:45pm, Boston Marriott Copley Place, 3rd, Brandeis

Soviet Meddling in American Politics during the Cold War Sat, December 8, 3:30 to 5:15pm, Boston Marriott Copley Place, 1st, Tremont 